IFN Working Paper No. 825, 2010

\title{
Hybrid Entrepreneurship
}

Timothy B. Folta, Frédéric Delmar and Karl Wennberg 
(C) INFORMS - Forthcoming in Management Science)

\author{
Timothy B. Folta \\ Krannert School of Management \\ Purdue University \\ 403 West State Street \\ West Lafayette, IN 47907-2056 USA \\ Phone: +1-765-494-9252 \\ foltat@purdue.edu \\ $\&$ \\ EMLYON Business School \\ Frédéric Delmar \\ Center for Research in New Venture Creation and Growth \\ EMLYON Business School \\ 23 avenue Guy de Collongue \\ BP 174 \\ 69132 ECULLY Cedex FRANCE \\ delmar@em-lyon.com \\ $\&$ \\ Research Institute of Industrial Economics (IFN) \\ P.O. Box 55665 \\ SE-102 15 Stockholm SWEDEN \\ Karl Wennberg \\ Imperial College Business School \\ Innovation \& Entrepreneurship Group \\ South Kensington Campus \\ London SW7 2AZ, UNITED KINGDOM \\ k.wennberg@imperial.ac.uk \\ $\&$ \\ Stockholm School of Economics \\ P.O. Box 6501 \\ SE-111 83 Stockholm SWEDEN
}

\footnotetext{
* We are grateful to Lee Fleming, the Associate Editor, two referees, Brian McCann, Steve Barley, Karin Hellerstedt, Zoltan Acs, Howard Aldrich, Jan Andersson and seminar participants at Drexel University, EMLYON, IESE Business School, INSEAD, the Max Planck Institute of Economics, the Ratio Institute, Växjö University, the Research Institute of Industrial Economics (IFN), and Purdue University. This study benefitted from financial support from the Swedish Institute of Labour Market Evaluation (IFAU), the Swedish Agency for Innovation Systems (Vinnova), the Swedish Foundation for Small Business Research (FSF), the Swedish National Board for Industrial and Technological Development (NUTEK), Handelsbanken Research Foundations and CIBER at Purdue. A previous version of this paper was awarded the U. S. Small Business Administration's Award for "Best Paper Exploring the Importance of Small Businesses to the U.S. Economy or a Public Policy Issue of Importance to the Entrepreneurial Community" at the 2006 Babson College Entrepreneurship Conference and appeared in the conference proceeding. All errors remain those of the authors.
} 


\title{
HYBRID ENTREPRENEURSHIP
}

\begin{abstract}
In contrast to previous efforts to model the individual's movement from wage work into entrepreneurship, we consider that individuals might transition incrementally by retaining their wage job while entering into self-employment. We show that these hybrid entrepreneurs represent a significant share of all entrepreneurial activity. Theoretical arguments are proposed to suggest why hybrid entrants are distinct from self-employment entrants, and why hybrid entry may facilitate subsequent entry into full self-employment. We demonstrate that there are significant theoretical and empirical consequences for this group and our understanding of self-employment entry and labor market dynamics. Using matched employee-employer data over eight years, we test the model on a population of Swedish wage earners in the knowledge-intensive sector.
\end{abstract}

Keywords: Hybrid entrepreneurship; Self-employment; Labour market dynamics; Transition determinants; Employee-employer data

JEL: J24; H39; L26

\section{Introduction}

The preponderance of research examining the entrepreneurial entry decision casts it as a dichotomous choice between entry and no entry, or between self-employment and wage work. This view of entry as an "all or none" phenomenon contrasts sharply with recent evidence suggesting that a significant proportion of all entrepreneurs engage concurrently in both—they initiate their ventures while simultaneously working for wages. Burke et al. (2008) found that "pure" entrepreneurs are outnumbered by individuals who mix their time in both selfemployment and wage work, and other scholars have described the prevalence of this phenomenon across multiple countries. ${ }^{1}$ In this paper we consider the theoretical and empirical implications of this type of entry strategy. We label this process hybrid entrepreneurship and the individuals who engage in it hybrid entrepreneurs. ${ }^{2}$

\footnotetext{
${ }^{1}$ Burke et al. (2008) followed 11,361 men and women from the British National Child Development Study and found that "pure" entrepreneurs were outnumbered by individuals who mixed their time in both self-employment and wage work. Evidence from the European Labour Force Survey indicates that a large proportion of the self-employed (11\% in Greece, $18 \%$ in France, 32\% in Sweden, and 68\% in the Netherlands) often combine self-employment with some other type of work (Strohmeyer and Tonoyan 2006). Renna (2006) recently noted that the incidence of dual jobholding is higher for the selfemployed than for wage workers. A number of studies have noted that over $50 \%$ of nascent entrepreneurs are also employed full-time for pay (Reynolds et al. 2004, Petrova 2005, Campbell and De Nardi 2007), leading Reynolds, et. al (2004: 41 ) to note that hybrid entrepreneurship is "one of the least understood features of nascent entrepreneurs".

${ }^{2}$ We distinguish this terminology from "part-time entrepreneurs" or "work mixers", which have a specific meaning in their respective literatures. The former emphasizes a strict distinction based on hours worked. We contend that hybrids can be
} 


\section{HYBRID ENTREPRENEURSHIP}

Hybrid entrepreneurship might be preferred to full immersion into self-employment to test the entrepreneurial waters and thereby learn about a venture's upside potential and their own fit in the entrepreneurial context. Less-confident entrepreneurs might rationally choose hybrid entrepreneurship to limit their sunk commitment while they gather evidence on their unknown capability. Small-scale entry via hybrid entrepreneurship may be characterized as a real option to invest heavily if early returns are promising and to exit if they are not. Such an incremental process may be particularly attractive to individuals with high switching or opportunity costs, or who are targeting uncertain opportunities, and might partially explain why many exit self-employment shortly after entering.

The theoretical implications noted above may have profound empirical implications for the study of entrepreneurial entry. Forcing hybrid entrepreneurs into mutually exclusive categories of wage work or self-employment obfuscates whether hybrid entry is the first step toward possible future immersion in self-employment. Moreover, it disallows consideration that the factors inspiring hybrid entry are different from those inspiring either selfemployment or wage work. The implications are not only curious, but fundamental, because prior work may report misleading determinants of self-employment entry if (a) the decision to immerse in self-employment is endogenous to hybrid entry, or (b) the determinants of hybrid entry are systematically different from the determinants of self-employment entry.

We have several objectives in this paper. First, we hope to elucidate the prevalence of hybrid entrepreneurship. We do so by tracking over a seven-year period, a sample of nearly 45,000 Swedish men who began a new wage job in 1994 with a firm in knowledge intensive sectors of the economy. While this focus limits the ability to generalize our results to all industries, Götzfried, (2004) noted these sectors accounted for over half of all jobs in the

more inclusive and need not be full-time wage workers or part-time self-employed. They need only have a primary wage job and a secondary job in self-employment. The work mixing literature is specifically concerned with predicting how individuals allocate their time across self-employment and wage activities (e.g., Parker 1997), an effort in which we are not interested. 


\section{HYBRID ENTREPRENEURSHIP}

Swedish economy in 2003 (46.4\% of manufacturing and 63.2\% percent of service). Second, we consider theoretical explanations for (a) why hybrid entry might influence selfemployment entry, and (b) why individuals might prefer hybrid entry to complete immersion in self-employment; and examine the empirical evidence around these issues. Third, we demonstrate the empirical implications of ignoring hybrid entrepreneurs by treating them as wage workers or self-employed. The empirical evidence supports the notion that hybrid entrepreneurs are prevalent and systematically different from those opting for direct entry into self-employment. Moreover, we find compelling evidence that hybrids have a much higher likelihood of entering into self-employment than non-hybrids, and that self-employment entry is significantly influenced by learning while in hybrid mode. Finally, our analysis suggests that distinguishing hybrid entry from self-employment entry is likely to have an impact on the coefficients predicting self-employment entry. These findings have strong implications for how we interpret prior research.

\section{Hybrid Entrepreneurship versus Complete Immersion in Self-Employment}

We define hybrid entrepreneurs as individuals who engage in self-employment activity while simultaneously holding a primary job in wage work. Despite their prevalence, hybrid entrepreneurs have largely escaped systematic study, being predominantly classified into mutually exclusive categories as self-employed or wage workers, but sometimes eliminated from samples altogether. ${ }^{3}$ Parker (2005) and Burke et al. (2008) recently cautioned scholars about treating self-employment and wage work as mutually exclusive categories. ${ }^{4} \mathrm{We}$ emphasize two reasons why entry into hybrid entrepreneurship may be unique from selfemployment entry or wage work.

\footnotetext{
${ }^{3}$ See unpublished appendix for reference to prior samples and how hybrids have been treated in studies using those samples.

${ }^{4}$ Parker (2005) theoretically challenged the traditional way of estimating wages when individuals "mix" wage work and selfemployment, arguing that a first-stage binary selection model is problematic under such a scenario.
} 


\section{HYBRID ENTREPRENEURSHIP}

First, the decision to eventually enter self-employment may be endogenous to the hybrid entry decision. Entry into hybrid status may influence self-employment entry. This will be the case if important learning takes place while a hybrid. A positive signal about performance prospects may inspire hybrids to leave wage work and enter self-employment, while a negative signal may induce abandonment of their self-employment activity. ${ }^{5}$ Without a compelling signal for either exercise or abandonment, many may persist in hybrid status. It is important to enunciate that the potential for learning is available for every hybrid entrepreneur, regardless of whether, ex ante, there was an explicit intent to investigate a transition to self-employment.

Second, the factors that induce hybrid entry may be systematically different from those that lead individuals to enter self-employment or remain in wage work. We present three rationales that each justify why systematic differences might obtain. We also offer predictions that might enable us to distinguish among the rationales, but that is of secondary importance.

\subsection{Theoretical Rationales for Hybrid Entry}

2.1.1 A Path to Supplementary Income. Individuals might combine selfemployment with a wage-earning position to gain an additional source of income. While empirical research has neglected it, self-employment may offer a particularly attractive "second" job because it provides a high degree of work schedule flexibility in combining work and family time (Renna 2006), potentially allowing individuals to determine the timing, the extent, and the direction of effort they deliver. This rationale suggests that hybrid entrepreneurs might be similar to wage-earning individuals engaged in a second wage job because of economic hardship and limits on hourly earnings in the primary job's earning capacity. We might expect that negative income shocks spur efforts to seek supplementary

\footnotetext{
${ }^{5}$ If a high percentage of part-time entrepreneurs are hybrids, this logic may explain why they tend to be less persistent than full-time entrepreneurs.
} 


\section{HYBRID ENTREPRENEURSHIP}

income through hybrid entrepreneurship. Building from the literature on "moonlighting" in a second wage job, this logic suggests that individuals engage in hybrid entrepreneurship if they have a lower salary in a primary job and a lower non-salary income, are married, and have more children (Kimmel and Conway 2001, Renna 2006). ${ }^{6}$ It is unclear, however, whether these qualities are distinguishable from those who enter immediately in self-employment, because there is evidence that those with low income select into self-employment (Bruce and Schuetze, 2004; Hyytinen and Rouvinen, 2008). ${ }^{7}$ It is also possible that high earning and capable individuals, such as university professors, may engage in hybrid entrepreneurship to supplement income if they have opportunities to do so at low marginal cost.

2.1.2. A Path to Nonmonetary Benefits. A second rationale individuals take on second jobs is to gain nonmonetary benefits that might not be available in their primary job. ${ }^{8}$ This rationale may have particular relevance for explaining second jobs as entrepreneurs, who frequently report a preference for their profession because it allows them flexibility to do what they please, whether pursuing a hobby or exploring an interest or seeking financial returns. Hybrid entrepreneurship may be preferred to a second wage position because it provides additional monetary and psychological benefits. For example, a comedian may have a "day" job and perform comedy on nights and weekends. We expect to see evidence that hybrid entrepreneurs are willing to sacrifice salary income to get these psychological benefits, much like the self-employed (Hamilton, 2000). Why would individuals prefer receiving nonmonetary benefits as hybrids rather than self-employed? While this question has not been addressed, it probably hinges on an unwillingness to sacrifice a wage job because of high opportunity costs, suggesting hybrid entrepreneurs are more-capable individuals and less

\footnotetext{
${ }^{6}$ To be clear, this literature on "moonlighting" does not imply the secondary job is illegal or tax evasive.

${ }^{7}$ It may be problematic to extrapolate these findings to our study because they consider hybrids as self-employed.

${ }^{8}$ Kimmel \& Conway (2001) and Renna (2006) advanced this rationale after having noted that dual jobs are most common among workers with a college education, which conflicts with the view that the majority of moonlighters earn low wages.
} 


\section{HYBRID ENTREPRENEURSHIP}

constrained by liquidity.

2.1.3. A Path to Transition. Hybrid entrepreneurship may provide a safe bridge for those explicitly considering a transition into self-employment. ${ }^{9}$ Compared to immediate entry into self-employment, hybrid entrepreneurship may be attractive because it avoids switching costs to preserve the flexibility and option value associated with delaying entrepreneurial entry. The cost of switching from wage work to self-employment may be significant and could involve lost retirement benefits with an employer, lost company seniority or status, lost sector-specific experience, the costs of raising entrepreneurial start-up capital, disruption of an accustomed lifestyle, lost employer-provided healthcare, other non-wage perquisites, or the stigma of entrepreneurial failure (Parker, 1996; 2005). ${ }^{10}$ These costs take on greater weight in the switching decision in the presence of uncertainty about the venture's prospects or the individual's fit in the entrepreneurial context. ${ }^{11}$ Hybrid entrepreneurs manage uncertainty by keeping a link with their current employer, while allowing them to experience entrepreneurship. ${ }^{12}$ Once they gain more information, they have the flexibility to decide whether to expand and exit their wage position, persist as a hybrid, or exit the venture

\footnotetext{
${ }^{9}$ A Wall Street Journal article (Robichaux, M. 1/9/1990. "The Part-Time Entrepreneur: Entrepreneur Takes a Leap Without Risking a Big Fall.”) chronicles the story of a doctor who, while earning a healthy income as the chief of orthopedics at a major hospital, started a business hoping to save companies money by offering therapy to employees with back injuries. Despite highly ambitious expansion plans, he faced very real risks to his business's future, partly because the medical community had yet to embrace his unknown therapy. Keeping his role at the hospital allowed him to mitigate those risks. In the article, Professor William Bygrave remarked: "It's not unusual for business professionals to drop more-secure careers if their own small businesses show promise. If they turn out successful, they'll make the dive." Even if the doctor's business failed, he could rely on his career at the hospital. "That one fallback position allows them to take the risk. Remember, they have a primary responsibility to feed families," noted Professor Bruce Kirchoff.

${ }^{10}$ Landier (2005) emphasizes that there may be stigma of entrepreneurial failure, but the multivariate evidence in the U.S. (Bruce and Schuetze, 2004) and in Europe (Hyytinen and Rouvinen, 2008) suggests that prior entrepreneurial spells do not lower wages upon exit from self-employment. Instead, individuals with low wages tend to select into self-employment.

${ }^{11}$ Dixit and Rob (1994) developed a model to characterize this option value in any occupational switching decision, whereas Parker (1996) suggested the real option model be specifically applied to switches between wage employment and selfemployment. O'Brien, Folta, and Johnson (2003) provide evidence that individuals maintain their option to defer selfemployment entry in the presence of higher exogenous uncertainty and higher switching costs. Caves (1998: 159) noted that the pattern of entry "invites interpretation in terms of entrants' diverse expectations and real options: entrants holding more positive expectations about their untested capabilities ... make larger initial commitments." While real option models tend to emphasize exogenous uncertainty.

${ }^{12}$ Jovanovic (1982) emphasized that entry is influenced by the uncertainty around whether an individual's capabilities match the entrepreneurial context, and the best way to ascertain the quality of the match is to enter and gain experience.
} 


\section{HYBRID ENTREPRENEURSHIP}

altogether. This rationale suggests the most likely prospects for hybrid entrepreneurship are individuals with higher switching costs or who, upon entry into hybrid status, can accumulate more information (i.e., resolve more uncertainty) about their own fit in the entrepreneurial context.

2.2. Theoretical Summary. The discussion above highlights three issues. First, since hybrids can learn about the potential of the venture or their own fit in self-employment, selfemployment entry may be endogenous to hybrid entry. This raises concerns about treating hybrids as self-employed. Second, we suspect that the rationales for entry into hybrid status are different from entry into self-employment, and it may be possible to distinguish among the theoretical rationales. If, compared to self-employment entrants, hybrid entrants have higher switching costs and less experience in the entrepreneurial context, they may be making an explicit attempt to investigate a transition to self-employment. They may be seeking nonmonetary benefits if they are willing to trade-off income for these benefits, are more educated, and have higher salary and non-salary incomes; although these expectations also obtain from the transitional rationale because those with higher opportunity costs should also have higher switching costs due to above-average conditions in their wage work. ${ }^{13}$ Hybrids are likely to be supplementing income if their entry is induced because of negative income shocks, or weak financial positions, or larger families, or there is clear evidence that selfemployment income increases overall income. The ability to discriminate between these rationales is hindered, however, because they sometimes lead to the same predictions and are not mutually exclusive. While it is easy to observe transitional events, this does not clarify the ex ante intention of the hybrid entrepreneur because regardless of the rationale, they may learn from their experience in hybrid entrepreneurship and adapt their intention. Third, even if

\footnotetext{
${ }^{13}$ The nonmonetary rationale emanates from the moonlighting literature and was developed prior to the transitional rational we offer. As the transitional rational suggests many of the same determinants, further attempts are needed to theoretically discriminate between these two theories.
} 


\section{HYBRID ENTREPRENEURSHIP}

it is difficult to discriminate among rationales, if any of them obtain there is justification for concern about prior work that disregards hybrid entrepreneurs.

In the next section we provide evidence about the prevalence of hybrid entrepreneurship, whether hybrid entry and self-employment entry have unique determinants, and whether hybrid status facilitates transition into self-employment.

\section{Method}

\subsection{Data}

The data we use area special (high-technology) extract from a set of three matched longitudinal data sources on the entire Swedish labor market that were gleaned from governmental registers and maintained for research purposes by Statistics Sweden. ${ }^{14}$ The first source is LOUISE — which has demographic and financial information for all legal residents of Sweden over the age of sixteen from 1989 onward. The second source is RAMS—which tracks employment flows in the labor market based on an annual mandatory survey for all firms having at least one employee or earning a profit. The third source is SRU—which tracks financial information for each firm and is submitted annually to the fiscal authorities for taxation purposes. The special abstract we use for analysis is called EPRO (Entrepreneurial Processes Database) and was commissioned for a broader project on entrepreneurship in hightechnology manufacturing or knowledge-intensive service sectors, which are thought to be important to the Swedish economy. Individuals were identified as working in these sectors if their employer was in an industry that met Eurostat and OECD classifications (identified in unpublished Appendix B), which are based on the ratio of research and development

\footnotetext{
${ }^{14}$ Statistics Sweden is a division in the Ministry of Finance with authority over all national statistics for Sweden, including those related to industry and trade. RAMS is an acronym for Registerbaserad Arbetsmarknadsstatistik, which in English is equivalent to "Register-based Labor Statistics." SRU is an acronym for Standardiserad Räkenskapsutdrag, which in English is equivalent to "Standardized Accounting Summary." We believe our data to be comparable to recent studies using matched employee-employer data for Denmark (Sorensen 2007) and Finland (Hyytinen and Ilmakunnas 2007)
} 


\section{HYBRID ENTREPRENEURSHIP}

expenditures to gross domestic product (Götzfried 2004). The EPRO extract covers any individual who was active in these sectors at any time from 1989 to 2002.

We constructed a risk set based on men, between the ages of 25 and 50,who began working as "employed" (and not involved in self-employment) for a high-technology manufacturer or knowledge-intensive service firm in 1994. A focus on men reduces unobserved heterogeneity around issues of family choices; a focus on newly employed eliminates problems with left-censoring, which occurs when a person becomes at risk of switching prior to our ability to observe them; and beginning in 1994 enables measurement of labor market experience since 1989 and avoids the worst of the recession in Sweden in the early 1990's.44,613 men become at risk of transitioning from their current job in 1994 to selfemployment, hybrid entrepreneurship, unemployment, or another job. They remain at risk until they enter self-employment or unemployment, or become deceased, or emigrate, or the end of the observation period in 2001.

\subsection{Identifying Labor Status}

We identify individuals' labor status using the occupational classification scheme employed by Statistics Sweden. The scheme distinguishes between "employed," "not employed," "selfemployed" (i.e., an ownership position in a proprietorship or partnership where they are working), and "self-employed in incorporation" (i.e., an ownership position in an incorporated business where they are working). Individuals are identified by labor status for each source (i.e., employer) of income during a year, and the number of sources is unconstrained. Their "primary" labor activity is determined at the time of the annual survey in November of each year. $^{15}$

\footnotetext{
${ }^{15}$ Many studies define labor market status based on the source from which individuals receive most income, which makes it challenging to accurately identify instances of simultaneous wage work and self-employment.
} 


\section{HYBRID ENTREPRENEURSHIP}

Wage workers. Individuals are defined as wage workers if they were "employed" and had no income or losses from self-employment (see footnote 15).

Self-employed. Individuals are defined as self-employed if their primary classification is either "self-employed" or "self-employed in incorporation."

Hybrids. Individuals are defined as hybrid entrepreneurs if, in a given year,

(1) their primary classification is "employed;"

(2) they have a secondary classification (the number of secondary classifications is unlimited) where they are "self-employed" or "self-employed in incorporation" or report selfemployment losses; and

(3) they are "employed" in the same firm as they were in the prior year.

Criterion 3 is imposed because it helps with the challenge of distinguishing between individuals who are simultaneously engaged in employment and self-employment versus individuals who move sequentially from employment to self-employment in the same year. Either simultaneous or sequential involvement can obtain if we apply only criteria (1) and (2). With the addition of criterion (3) we believe it is very unlikely that sequential involvement can obtain, because the individual would need to have quit an employed position, then entered self-employment, and then returned to employment with the same firm all in the same year. ${ }^{16}$

Sweden has several qualities that might potentially impact a preference for hybrid entrepreneurship. The difference between income tax and corporate tax is high compared to the OECD mean. This might encourage individuals to divert some income into selfemployment earnings (Gentry and Hubbard, 2000; Henrekson, 2005), increasing the likelihood of hybrid activity. This might be expected to reduce the likelihood of ultimate transition to self-employment, but it might also raise transition rates as it opens up

\footnotetext{
16 If individuals satisfied criteria (1) and (2) but not criterion (3), we identified them as wage workers. A potential limitation with this approach is that we do not know with certainty whether the 1,926 individuals identified as wage workers were not actually simultaneously engaged in self-employment. If, in fact, some of them were, it would be more difficult to find significant effects, indicating that our treatment of hybrids is a conservative one. However, we note that in analyses not reported here, we did separate the 1,926 men into a fourth classification that did not alter the conclusions of our findings.
} 


\section{HYBRID ENTREPRENEURSHIP}

opportunities to learn about self-employment opportunities. The country's strong labor protection laws might reduce switching costs, which should decrease the prevalence of hybrids. These characteristics may influence the robustness of our findings.

\subsection{Independent Variables}

Our variables, defined in Appendix A, are designed to correspond to the factors that help us distinguish between theoretical rationales for hybrid entry. The supplemental income rationale hinges on individuals' financial (Salary Income, Negative Change in Salary Income, NonSalary Income, Negative Change in Non-Salary Income, Household Wealth) and family (Married, Number of Children) situation. The nonmonetary benefits rationale hinges on opportunity costs, which is approximated by income and capabilities (Education Percentile, Total Number of Jobs, Time Unemployed). Finally, the transitional rationale hinges on entrepreneurial experience (Self-Employment Experience, Target Industry Experience, Parental Self-Employment Experience) and switching costs (Industry Tenure, Employer Tenure, Employer Size, Employer Age). Employer size and age are proxies for switching costs because perquisites and seniority benefits are more prevalent in larger and older firms. Employer Age is measured as three dummy variables because we are unable to observe firm births prior to 1989. We control for age, hybrid experience, citizenship, and the role of partners.

\section{Results}

We first examine the prevalence of hybrid entrepreneurship relative to wage work and selfemployment, and note the transition rates from one status to another. Next, we examine the empirical evidence for whether there are systematically different predictors for hybrid and self-employment entry, and for the proposed rationales. Finally, we examine the dynamic 


\section{HYBRID ENTREPRENEURSHIP}

effect of hybrid entrepreneurship on self-employment entry. If there are systematic differences or evidence that self-employment entry is endogenous to hybrid entry, this is a strong indication that hybrid entrepreneurs should be treated separately and that there is selfselection into this category.

\subsection{Transition Rates, Hybrid Entrepreneurship, and Self-Employment}

Our main analyses are based on three primary classifications: wage work, self-employed, and hybrid. ${ }^{17}$ Table 1displays the distribution of labor classifications over the years 1994 to 2001 . In 1994 the sample consisted only of wage workers. It is noteworthy that by $2001,3.23 \%$ of the individuals are self-employed, while $2.55 \%$ are hybrids. Thus, in 2001 hybrids represent over $44 \%$ of all self-employment activity. This ratio seems comparable to those in prior studies noted earlier. The table also identifies the number of entries into each classification over time. Entries are observed in the year an individual leaves employment and switches to the new labor status. There were 5,548 entries between 1995 and 2001, and hybrid entries represent over $58 \%$ of all entries. Thus, individuals switched into and out of hybrid status more frequently than self-employed status. The last set of analysis indicates that over $21 \%$ of all self-employment entries are preceded by hybrid activity. While this may seem low to support the transitional rationale, we would not expect many hybrids to enter self-employment if, in fact, individuals entered hybrid status while there was a high degree of uncertainty. It is interesting to note that individuals showed an increased preference for direct entry into selfemployment in 2000 and 2001 compared to earlier periods. This period coincides with the culmination of an economic boom where the access to venture capital financing and entry rates was at records high in Sweden, the US and elsewhere. Similar to evidence from venture

\footnotetext{
${ }^{17} \mathrm{We}$ also ran models discriminating between self-employment types (proprietorship/partnership or incorporation) of hybrid types (proprietorship/partnership or incorporation) but ultimately found that distinguishing among these types did not substantively alter our conclusions. Accordingly, we preferred to present the simplified treatment of these variables.
} 


\section{HYBRID ENTREPRENEURSHIP}

capital activity, there might be a lagged effect of self-employment entries subsisting throughout 2001 after the burst of the dot-com bubble.

[Insert Tables $1 \& 2$ About Here]

Table 2 shows the labor status transitions from year to year. We predetermined that all self-employed remain in self-employment, since we stopped observing those individuals upon entry. Panel A shows that $98.1 \%$ of men remain in wage work from one year to the next. Wage workers most frequently transition to Hybrid (1.2\%), and about $0.7 \%$ transition directly to Self-Employed. It is interesting to note that the rate of transition to Self-Employed is over twelve times higher for hybrids than for those in Wage Work (8.5\% to $0.7 \%)$. The data also show that hybrids are likely to transition back to wage work at a rate of $36.6 \%$, and only $54.9 \%$ persist in hybrid from one year to the next. ${ }^{18}$ It appears that hybrid is frequently a transitory state often ending in entry into self-employment.

Panel B of Table 2 divides Hybrid into five categories to consider whether the intensity of hybrid activity bears upon transitions to Self-Employed, Wage Work, or other levels of Hybrid Intensity. Hybrid Intensity is defined by the percentage of a hybrid's selfemployment income divided by Salary Income. Hybrids with positive Hybrid Intensity (i.e., earning positive self-employment income, Hybrid Intensity 3-5) transition to Self-Employed at higher rates than those with negative levels (Hybrid Intensity 1-2). Transition rates to SelfEmployed are particularly high for Hybrid Intensity 4 (13.0\%) and Hybrid Intensity 5 (38.5\%). Hybrid Intensity does not seem to influence the transition back to Wage Work.

[Insert Tables 3 and 4 About Here]

\footnotetext{
${ }^{18}$ This rate of persistence for hybrids is much lower than rates reported for self-employed in prior studies.
} 


\section{HYBRID ENTREPRENEURSHIP}

\subsection{Explaining Entry into Hybrid Entrepreneurship and Self-Employment}

4.2.1. Bivariate analysis. Table 3 reports the means of our variables across wage work and type of entry. The entries reported in column 3 are those where an individual moves directly from Wage Work to Self-Employed. They can be contrasted with those in column 4, where we report individuals entering Hybrid. In column 5 we report significant differences between the two forms of entry, which is of primary importance to us. This bivariate analysis reveals that individuals choosing the alternative entry paths are quite different along many dimensions.

Of secondary importance is how this data supports the three rationales. There seems to be most evidence in support for the transitional rationale, as individuals prefer hybrid entry when they have less experience in the entrepreneurial context (less Self-Employment Experience and Target Industry Experience), higher switching costs (greater Industry Tenure, Employer Size, and Employer Age), and higher opportunity costs (higher Salary Income, higher Education Percentile, fewer Total \# of Jobs, and more Time Unemployed). The only variable that did not align with the transitional rational is Employer Tenure, a proxy for switching costs. The evidence around opportunity costs may also be interpreted as support for the nonmonetary benefit rationale, and potentially supporting the supplementary income rationale if we interpret the most capable individuals as the ones with the most opportunity to supplement income. Otherwise, with the exception that married men prefer hybrid, the bivariate analysis shows little evidence that financially-constrained individuals choose hybrid to supplement income. In fact, more negative salary income shocks are associated with a preference for Self-Employed over Hybrid. The evidence around Salary Income seems to also contradict the view that financially constrained individuals choose hybrid. For example, the mean hybrid entrant is earning 276,395 Swedish Kronor (SEK, or approximately $\$ 34,550$ in 1994) from a paid job at time of entry, whereas the mean self-employed entrant is earning 


\section{HYBRID ENTREPRENEURSHIP}

233,384 SEK from a paid job at time of entry. We also note that $39 \%$ of all self-employed entrants are in the lowest quintile of salary income, compared to only $19 \%$ for hybrid entrants. Hybrids tend to come disproportionally from the four highest quintiles of salary income.

To further exploit the panel nature of our data and explore whether patterns in salary yield clues about the three rationales, we calculate changes in income the year of entry. In Table 4 we report income averages for all hybrid entrants and for hybrid entrants in the different centiles of Salary Income. If hybrids were supplementing income, we would expect them to maintain or increase their salary level, and make additional self-employment income. This pattern is observed for the average hybrid. For example, upon entry the average hybrid earns additional salary income of SEK 13,261 and self-employment income of SEK 922. Closer inspection, however, suggests that this pattern is only applicable to the hybrids in the highest quintile of salary income. While not reported in the table, $17.9 \%$ of all hybrid entrants had increases in salary and positive self-employment income. If hybrids were interested in nonmonetary benefits, we might expect them to sacrifice salary income and have lower total income after entry. We observe this pattern for hybrid entrants in the $1^{\text {st }}$ centile of salary income. While not reported in the table, $25.8 \%$ of all hybrid entrants had lower salary and lower total income. We do not believe that Table 4 helps in diagnosing the transitional rationale. Negative self-employment earnings or lower total income might represent willingness to pay an option premium to gain information about the venture's upside potential or the individual's fit in self-employment. Positive self-employment earnings might represent confirmation that the venture is worth pursuing. The fact that high-earners tend to have higher variances in self-employment income suggests they are likely to start the ventures with the highest potential.

[Insert Table 5 about here] 


\section{HYBRID ENTREPRENEURSHIP}

4.2.2. Multivariate Analysis. Table 5 shows the coefficients and marginal effects of a multinomial logit model used to examine whether there are differences in the determinants of self-employed entry (with no preceding hybrid activity), hybrid entry, and no entry. The key assumption of multinomial logit is that the alternatives are independent, which was confirmed using the Hausman test. Moreover, tests of individual coefficients confirm significant differences between the predictors of the three alternatives. This evidence should raise concern about treating hybrids as if they were self-employed or non-entrants.

The conclusions drawn earlier about the relative potency of the rationales is largely confirmed. Hybrid entry is preferred to self-employment entry by individuals that are more capable (more education, fewer prior jobs, less time in unemployment), have lower switching costs (longer industry tenure and working in larger firms), and have less Self-Employment Experience ${ }^{19}$ Consistent with the view that hybrid entry is preferred when individuals have less experience in the entrepreneurial context, we also report (in an unreported model) that hybrid entry is preferred when men target ventures in an industry different than their existing one. ${ }^{20} \mathrm{~A}$ final variable, Employer Tenure, reveals some support for the expected relationship between switching costs and choice. As expected, it indicates that individuals with longer employer tenure are less likely to switch from wage work to hybrid or self-employed entry (Özcan and Reichstein 2009). In contrast to expectations, however, men with low employer tenure have a preference for self-employed entry rather than hybrid entry. The coefficients suggest, however, that there is an increased preference for hybrid entry when they have been with a firm for more than five years.

\footnotetext{
${ }^{19}$ Our finding that more-educated individuals prefer self-employment to wage work is consistent with Evans and Leighton (1989), who interpreted this as evidence concerning the relative payoff of education, but they did not test how education affects entry into hybrid entrepreneurship. We also note that in unreported models we found hybrid entry was preferred to self-employment with more macroeconomic uncertainty (volatility of stock market index), consistent with the transitional rational.

${ }^{20}$ We could not add the Target Industry Experience variable to the model presented in Table 5 because it does not vary across the "no entry" alternative. Therefore, in the unreported model we limited the choice set to Self-Employed and Hybrid.
} 


\section{HYBRID ENTREPRENEURSHIP}

The evidence in Table 5 confirming significant differences between self-employed and hybrid entry is robust to every alternative specification we explored. In conducting these robustness checks, we found only minor differences in individual coefficients affecting our interpretation of the various rationales. We replaced Salary Income with dummies for the quintile of Salary Income for each individual, and find no significant differences across quintiles. Nor do we find differences when we eliminate outliers in salary income or household wealth. We also split the sample into the lowest and highest quintiles of 1994 Salary Income, but the coefficients across these quintiles showed little variation, and significant effects were consistent with Table $5 .^{21}$ When splitting the sample into five different age cohorts, we get remarkably consistent results across these cohorts. The most evident exception is the negative relationship between Time Unemployed and the preference for hybrid over self-employed entry is valid only for the lowest two age cohorts. Finally, we split the sample into wage workers in manufacturing versus service industries in 1994. Again, the results were consistent across broad industry types, with a few exceptions. In contrast to those in service industries, individuals in manufacturing industries with lower income (salary and non-salary) and more education prefer hybrid to self-employment. ${ }^{22}$

In the next section, we dig more deeply into the dynamic implications of hybrid status. We have argued that learning and adaptation should be available to any hybrid, whether the intent to learn is explicit from the outset (as in the transitional rationale) or not (as in the supplementary income and nonmonetary benefits rationales). Since there is evidence consistent with the transitional rationale, however, we might anticipate that hybrid entry will have a robust influence on self-employment entry.

\footnotetext{
${ }^{21}$ In general, there was less significance among the coefficients in these reduced sample sizes.

${ }^{22}$ We also created a fourth alternative - where individuals take on a secondary wage job - and compared the coefficients to those relating to the Hybrid alternative. We found substantially different coefficients, which suggests that hybrid entrepreneurship is unique from second wage jobs. Compared to those starting a secondary wage job, Hybrids had higher salary income, more negative changes in salary income and non-salary income, more parental self-employment experience, more education, less time in unemployment, less likely to be between 25 and 35 years of age, less entrepreneurial experience, less experience in the target industry, more hybrid experience, and less industry experience.
} 


\section{HYBRID ENTREPRENEURSHIP}

[Insert Table 6 About Here]

\subsection{Examining the Effect of Hybrid Entrepreneurship on Self-Employment Entry}

Table 6 shows the results of conditional fixed effect logit models used to ascertain whether hybrid entrepreneurship facilitates a transition to self-employment. By incorporating independent variables associated with the hybrid experience in models of all 2,327 selfemployment entries, regardless of whether they were preceded by hybrid entry, we can isolate the causal effect of hybrid status on self-employment in a robust way (Heckman and NavarroLozano 2004). The conditional fixed effects model is ideal for isolating these effects because it controls for sources of unobserved heterogeneity that may account for individual preferences to transition, while at the same time controlling for the self-selection into hybrid status. We will emphasize the effects of these hybrid variables in our discussion. However, note that other coefficients might change relative to those noted in column 1 of Table 5 due to the presence of these hybrid variables, the inclusion of all self-employed entries preceded by hybrid entry, or the fixed effects specification.

Column 1 depicts a model for a set of variables identical to those presented in Table 5. Columns 2-5 add variables relating to hybrid activity and suggest that they have a strong influence on self-employment entry. The addition of these Hybrid variables does not substantively alter the coefficients of the other variables. ${ }^{23}$ Column 2 adds the variable Hybrid. If hybrids enter with an explicit intent to consider transition into self-employment, they should transition more frequently than wage workers, as we observed in Table 2 . The significant positive coefficient for Hybrid is 3.64, and by taking its exponential we obtain the

\footnotetext{
${ }^{23}$ The coefficients for Industry Tenure are reduced relative to model 1, suggesting a correlation between the length of time a person works in an industry and the tendency to become a hybrid.
} 


\section{HYBRID ENTREPRENEURSHIP}

odds ratio, which suggests that hybrids are over thirty-eight times more likely to transition to self-employment. $^{24}$

We also consider indicators of learning and uncertainty reduction while a hybrid, meant to approximate the feedback the individual gets about the self-employment opportunity while in hybrid status. Significance of these factors need not be linked to an ex ante intent to transition, but would certainly indicate that self-employment entry is endogenous to hybrid entry. Column 3 adds Hybrid Self-Employed Income, which measures the self-employed income or loss obtained as a hybrid entrepreneur that year. The positive coefficient reveals that hybrids earning more self-employed income transition more frequently to self-employed. Calculation of the odds ratio suggests that earning an additional 10,000 SEK will increase by $18 \%$ their likelihood of transitioning to self-employed. Column 4 adds Hybrid Intensity, which measures the ratio of Hybrid Self-Employed Income / Salary Income. Hybrid Intensity significantly increases the transition to self-employment. A one percent increase in intensity raises the likelihood of transitioning by $5 \% .{ }^{25}$ When we consider dummies for different degrees of Hybrid Intensity, the effect of this variable appears non-linear. At the highest levels of Hybrid Intensity is there an effect on transition to self-employment. Compared to the base level of Hybrid Intensity 3 ( $0 \leq$ Hybrid Intensity< 0.05), hybrids in Hybrid Intensity 4 (0.05 $\leq$ Hybrid Intensity< 0.20) are twenty-eight times more likely to transition, and hybrids in Hybrid Intensity 5 (Hybrid Intensity $\geq 0.20$ ) are 143 times more likely to transition. While there is some evidence that hybrids in Hybrid Intensity 1(Hybrid Intensity< -.05), the lowest level of Hybrid Intensity, are more likely to transition than those in the base level, this result does not hold up when we eliminate the 72 hybrids (out of 419) that enter self-employment in

\footnotetext{
${ }^{24}$ In unreported models we distinguished between hybrids in proprietorships and partnerships versus hybrids in incorporated businesses and found that very similar results across these two groups.

${ }^{25}$ In unreported models, to assess whether macroeconomic uncertainty moderated the effect of hybrid experience, we interacted a measure of macroeconomic uncertainty (based on stock market data) with Hybrid Self-Employed Income and Hybrid Intensity, separately. We found a significant interaction effect - the positive effect of high income/intensity was on self-employment entry was stronger the lower the uncertainty and was weaker the higher the uncertainty. This result reinforces the role of learning in hybrid mode.
} 


\section{HYBRID ENTREPRENEURSHIP}

a different firm. Thus, only the hybrids with the greatest proportion of self-employment income tend to enter. The fact that low earning hybrids do not enter may not indicate a lack of intent to transition, but may suggest that without a compelling performance signal, individuals persist in hybrid status. $^{26}$

Finally, column 6 of Table 6 displays a conditional fixed effects logit model specifying self-employment entry as many prior studies have done, equating hybrid entry with self-employment entry. Our intent here is to demonstrate the empirical implications of ignoring hybrids when estimating self-employment entry. Comparing the coefficients in column 6 to columns 1-5 suggests that variables might have different effects across different specifications. Note particularly the effect of variables which change signs across specifications - Employer Tenure; which are significant in one specification but not in the other - Married, Number of Children, Total Number of Jobs, Employer Age, and Industry Tenure; and which change considerably in magnitude - Salary Income, Time Unemployed, and Age 25-30.Consequently, how one treats hybrids has a significant bearing on the conclusions drawn for the determinants of self-employment entry. Considering hybrid entry equivalent to self-employment entry, as we have done in column 6, yields coefficients substantially different from models treating self-employment entry separately from hybrid entry, as done in columns $1-5$. We believe this evidence is a strong call to treat these phenomena separately.

\section{Discussion}

Assumptions about the dichotomous nature of entrepreneurial entry are so entrenched in social science research that little work has yet to investigate it empirically. In some

\footnotetext{
${ }^{26}$ In support of this, we revisited the multinomial logit model on the initial entry choice, altering the definition of Hybrid according to whether they were high intensity (Hybrid Intensity 4 and 5) or low intensity (Hybrid Intensity 1, 2, and 3). Again, the results were largely consistent across models, and with those reported in Table 5. The low intensity model coincided with stronger effects for age. For example, younger people were more likely to prefer hybrid to self-employment, whereas older people were more likely to prefer self-employment to hybrid.
} 


\section{HYBRID ENTREPRENEURSHIP}

perspectives, it is assumed that individuals will switch and commit themselves if their expected utility in self-employment exceeds their utility in wage work. This view implies that there is no intermediate strategy that potential entrepreneurs might follow to gain insight into the distribution of expected outcomes (e.g., Kihlstrom and Laffont 1979). While some studies have recognized that mixing wage work and self-employment is a possible alternative, no extant research has investigated whether hybrid entry has different determinants than selfemployment entry or no entry, nor has prior research considered the dynamic implications of hybrid entry. Our theoretical model and empirical results point to the importance of hybrid entrepreneurship and imply that treating it as self-employment is problematic. This takes on greater importance when one considers that hybrids represent a significant proportion of all entrepreneurial episodes and an even greater proportion of transitions into and out of entrepreneurship. We believe we are the first to systematically document the prevalence and influence of this category of entrepreneurship. Our paper has three broad implications for research on self-employment.

First, hybrid entry influences self-employment entry but does not determine it. Our longitudinal study of Swedish men revealed that both absolute and relative financial payoffs in hybrid status determine whether individuals transition to self-employment. Because rates of transition hinge on financial performance as a hybrid, our results support the expectation that the reduction of uncertainty through learning about entrepreneurial performance is an important benefit from hybrid entrepreneurship. This opens up the possibility that every hybrid is a candidate for self-employment, and contradicts those who believe counts of hybrids may over-represent their importance. We emphasize that in many cases it appears to be an explicit part of the process of entry. Even where transition is not explicitly considered ex ante, hybrid entrepreneurship offers the potential to learn and ultimately transition. 


\section{HYBRID ENTREPRENEURSHIP}

Second, hybrid entry has unique determinants from self-employment entry. Moreover, we offer three potential rationales for why preferences for hybrid entry might obtain, and present evidence around the relevant potency of these rationales. Our results suggest that the preference for hybrid entry is fundamentally and positively influenced by an individual's switching costs, uncertainty around the entrepreneurial context, and the quality of their human capital. While this is consistent with either an explicit intent to transition or seek nonmonetary benefits, it may also be consistent with high earners who supplement income because they have opportunities to do so. There is little evidence that financially constrained individuals choose hybrid entrepreneurship to supplement income. We encourage readers to recognize the need for future research to sort out the relative importance of these rationales. Our primary intent was to justify why hybrid entrepreneurship might be unique and to supply evidence around its uniqueness.

Third, our results also show that although ignoring hybrid entry might lead to an underspecification of the entry model, a more-serious error obtains if hybrid entrants are classified as self-employed entrants. Our data suggest that when this occurs, coefficients are substantially different from what would obtain if the two types of entrants were distinguished. Based on these findings, we encourage scholars studying self-employment entry to either (a) identify only full entries into self-employment and include a dummy for those in hybrid entrepreneurship, or (b) consider that hybrid entry is an alternative to self-employed entry through a multivariate model. These considerations take on even greater weight given the prevalence of this phenomenon, which makes it likely the classification of hybrids will have a strong impact on studies comparing self-employment entry across industries and economies. We caution against treating self-employment and wage work as mutually exclusive categories. 


\section{HYBRID ENTREPRENEURSHIP}

Our findings provide some additional evidence worth highlighting. The findings concerning firm size corroborate recent findings on how entrepreneurial activity is spawned disproportionately from small firms (Sørensen 2007, Elfenbein et al. 2008, Parker 2009) but provides new evidence that the smallest employers are most likely to spawn self-employed entry, while hybrids tend to emerge from significantly larger firms, and those staying in wage work are in the largest and oldest firms. We were surprised that individuals with longer employer tenure were more likely to enter self-employment than hybrid status. This result stands in contrast to our expectations and the results for our other measures of switching costs, which indicated that those with the lowest switching costs gravitate toward selfemployment, those with the highest switching costs remain in wage work, and those with intermediate switching costs choose hybrid entrepreneurship. The lack of significance for employer tenure may be due to our choice to limit the risk set to individuals beginning with an employer in 1994, which has the effect of reducing the distribution of the tenure variable, but has other obvious advantages noted earlier. This result may also be due to our focus on high technology workers, among which tenure might be a signal of weak ability. We found it interesting that while a lack of self-employment experience leads to a preference for hybrid, individuals with hybrid experience also seem to prefer hybrid to self-employment entry. This suggests not only that the specific type of experience (hybrid or self-employment) is critical to entry choice, but also corroborates the path dependency in entrepreneurial careers. We know of no prior work having distinguished between these types of experiences.

\subsection{Limitations and Future Work}

While we believe we have used a unique data set to explore a labor group whose existence prior studies have only suggested, there are some limitations. As already noted, more can be done to distinguish between the three theoretical rationales for hybrid entry. Confirmation of 


\section{HYBRID ENTREPRENEURSHIP}

the transitional rationale might gain support if able to examine whether choice is driven by differences in uncertainty or risk across sectors (Parker 1997) or differences in risk tolerance across individuals (Kihlstrom and Laffont 1979). To study the nonmonetary rationale, survey data is needed to ascertain the psychological motivations of individuals.

We note that these rationales represent supply side explanations, and it is likely that demand side arguments offer complementary explanations. Firm demand for labor might change due to changes in the treatment of payrolls and benefit packages across types of employees (Tolbert 1996), such as part-time versus full-time (Rotchford and Roberts 1982), contract versus paid (Barley and Kunda 2001), and temporary versus contingent workers (Gallagher 2002). These factors may not only influence a firm's demand for wage workers, but may also create opportunities for new ventures to form. Firm's may also have different tolerances for employees that are hybrids. Public sector employers, such as universities, can appropriate returns to employee innovations (Zucker, Darby and Armstrong 1988). Some firms may aggressively pursue non-compete covenants to prohibit their employees to start potentially competing businesses. Prior research has shown that non-compete covenants are an obstacle to entrepreneurship (Stuart and Sorenson 2003, Saxenian 1985), and many of these businesses started "on the side" would surely qualify as hybrid entrepreneurship.

While there are important advantages to our design, there remain opportunities for future work. We chose to study men because of unobserved differences among men and women due to variations in time allocation to family and children, and our data do not allow us to control for these differences. Future work should focus on how women use hybrid entrepreneurship. Research on moonlighting suggests that women and men might differ substantially (Kimmel and Powell 1999, van Maanen 1975). We investigate knowledgeintensive industries, yet it is likely that there exist important industry differences in the possibility of becoming hybrid and then transferring to full-time self-employment. Our data 


\section{HYBRID ENTREPRENEURSHIP}

suggests that industries differ in the rates of entry into hybrid versus self-employment. ${ }^{27}$ While we controlled for industry differences in our study, and tested for differences across service and manufacturing industries, further research should test whether hybrids are pertinent in industries outside our study. Data on professional status might represent one of the most important research possibilities for further studies on hybrid entrepreneurship (Tolbert 1996). Anecdotal evidence suggests that hybrid status varies greatly with the individual's professions. Police, academics, and medical doctors represent well-known categories of hybrids. Should monetary benefits be important, one should observe more hybrid entrepreneurs among those who are on a fixed salary or are unable to expand their hours/pay in the main activity.

Wage data would help confirm whether hybrids are more productive than others and a way for them to optimize their monetary and nonmonetary utility. It is possible hybrids are less productive than others, and that they represent free riders who successfully exploit the two parallel systems of employment and self-employment. More exposure is needed to the full causal chain by which experience as a hybrid can influence self-employment. We have argued that it provides information for entry choice, but it may also have implications for subsequent performance in self-employment. Finally, it might be interesting to explore whether hybrid behavior is related to individuals' social value versus economic value, traditions, or institutional norms. All in all, the labor market role, form, and economic function of hybrid entrepreneurship represent challenging arenas for future research.

\subsection{Implications for Entrepreneurship}

We believe that consideration of hybrids invites implications beyond those studied here. For example, since hybrids tend to be more capable individuals, we might expect them to start

\footnotetext{
${ }^{27}$ See unpublished Appendix B.
} 


\section{HYBRID ENTREPRENEURSHIP}

more high growth businesses than the self-employed. We might also expect hybrids who ultimately enter entrepreneurship to perform better than direct entrants because of the chance to preview the opportunity based on more feedback. Consider how it might influence our understanding of some of the fundamental puzzles surrounding entrepreneurship.

- Kihlstrom and Laffont (1979) have argued that risk attitudes are a distinguishing feature of entrepreneurs, yet the evidence is less than clear. Perhaps hybrid entrepreneurship offers an alternative for more risk-averse individuals to simulate the self-employment experience first-hand, potentially explaining why we do not observe differences in risk attitudes between entrepreneurs and wage workers.

- Liquidity constraints (Evans and Jovanovic 1989, Taylor 2001) may be less binding for hybrid entrepreneurs, who enter on a smaller scale, which might explain the divergence of findings in this line of research. Ironically, liquidity constraints might be exacerbated for "more capable" individuals who will only transit to self-employment conditional on starting up at a bigger scale to compensate for their higher opportunity costs.

- Returns to human capital (Lucas 1978, Bates 1990) may be different for hybrid entrepreneurs because they are expected to have higher opportunity costs. A metaanalysis of 90 available studies by van der Sluis et al. (2004) indicated that education has neither a clear-cut positive nor a negative effect on an individual's decision to become self-employed. A possible reason for this confusing result might be the treatment of hybrid entrepreneurs in those studies.

- The high exit rates reported in earlier studies of self-employment (e.g., Bates 1990, Evans and Leighton 1989, Taylor 1999) might be partially explained by their being unable to distinguish the fully self-employed from hybrid entrepreneurs who may be rationally experimenting rather than failing. High upside potential and limited 


\section{HYBRID ENTREPRENEURSHIP}

downside risk should characterize hybrid ventures. This also suggests that the decision to exit self-employment activity is endogenous to hybrid entry.

- Hybrid entrepreneurship corresponds to increased emphasis on nonstandard work arrangements (Kalleberg 2000), where workers are increasingly working part-time, have temporary or contract work, and engage in holding multiple jobs or moonlighting (Kimmel and Powell 1999). For example, the number of temporary jobs increased 50\% from 1990 through 1999 in Sweden (Holmlund and Storrie 2002), and the trend is similar in other countries (Kalleberg 2000). This study suggests that hybrid entrepreneurs represent a distinct and growing category on the labor market that should be added to this important topic of research.

Our findings also have important public policy implications. If entrepreneurship is to be encouraged via government efforts (as is the case in virtually all countries), policy efforts might facilitate hybrid activity, which is currently - if anything - actively discouraged. A potential policy variable to consider is non-compete covenants (Stuart and Sorenson 2003). These covenants are asymmetrically applicable to highly capable individuals, which are the most likely candidates for hybrid entrepreneurship. Lending institutions might be encouraged to make funding available for hybrids, to offset negative stereotypes of hybrid entrepreneurs. Finally, education programs should highlight the advantages of this incremental approach.

\subsection{Conclusion}

Prior research has caste individuals as always choosing between wage work and entrepreneurship. This research highlights the importance of considering hybrid entrepreneurship as a distinct process of entrepreneurial entry that enables learning and may be particularly useful to highly capable individuals lacking entrepreneurial experience. Recent data suggests that such behavior is prevalent in various international and institutional settings. 


\section{HYBRID ENTREPRENEURSHIP}

Our theoretical model and empirical results caution against ignoring or trivializing this type of entrepreneurs. 


\section{HYBRID ENTREPRENEURSHIP}

\begin{tabular}{|c|c|}
\hline \multicolumn{2}{|c|}{ Appendix A: Variable Definitions } \\
\hline Variable Name & Definition \\
\hline Wage work & $\begin{array}{l}\text { Individual has a primary classification of "employed" and has no secondary classifications in } \\
\text { self-employment }\end{array}$ \\
\hline Self-Employed & Individual has a primary classification of "self-employed" or "self-employed in incorporation" \\
\hline Hybrid & $\begin{array}{l}\text { Individual has a primary classification of "employed", at least one secondary classification of } \\
\text { "self-employed" or "self-employed in incorporation, and is employed with the same firm as the } \\
\text { previous year. }\end{array}$ \\
\hline Salary Income & Log of Income from "employed" status \\
\hline Negative Change in Salary Income & $\begin{array}{l}\log \left(1+\left(\text { Salary Income - Salary Income } e_{t-1}\right) / \text { Salary Income }\right. \\
t-1) \text { if }<0,0 \text { otherwise. Note, Salary } \\
\text { Income was not logged. }\end{array}$ \\
\hline Non-Salary Income & Yearly income or loss from capital gains (Swedish Kronor/1000000) \\
\hline $\begin{array}{l}\text { Negative Change in Non-Salary } \\
\text { Income }\end{array}$ & $\log \left(1+\left(\right.\right.$ Non-Salary Income - Non-Salary Income $\left._{t-1}\right) /$ Non-Salary Income $\left.e_{t-1}\right)$ if $<0,0$ otherwise \\
\hline Household Wealth & Log of total household wealth \\
\hline Household Wealth Dummy & Dummy variable $=1$ if individual's household wealth $>500000$ Kronor \\
\hline Married & Dummy variable $=1$ if individual is married \\
\hline Number of Children & $\#$ of children under 18 in the household \\
\hline Education Percentile & Individual's percentile rank in years of education in the sample \\
\hline Total Number of Jobs & Number of different firms individual has worked with since 1989 \\
\hline Time Unemployed & Log of number of days individual had been in unemployment in the prior year \\
\hline Age $25-30$ & Dummy variable $=1$ if individual between 25 and 30 years old \\
\hline Age $30-35$ & Dummy variable $=1$ if individual between 30 and 35 years old \\
\hline Age $35-40$ & Dummy variable $=1$ if individual between 35 and 40 years old \\
\hline Age $40-45$ & Dummy variable $=1$ if individual between 40 and 45 years old \\
\hline Age 45-50 & Dummy variable $=1$ if individual between 45 and 50 years old \\
\hline Age $>50$ & Dummy variable $=1$ if individual over age 50 \\
\hline Self-Employment Experience & $\begin{array}{l}\text { Dummy variable }=1 \text { if individual has at least } 1 \text { episode in self-employment in primary labor } \\
\text { status classification }\end{array}$ \\
\hline Target Industry Experience & $\begin{array}{l}\text { Dummy variable }=1 \text { if individual entered Self-Employment or Hybrid in the same industry in } \\
\text { which they were a wage earner immediately previous to their entry }\end{array}$ \\
\hline Experience & Dummy variable $==1$ if at least one parent was previously self-employed \\
\hline Industry Tenure & Log of number of years individual has worked in their current 2-digit industry \\
\hline Employer Tenure & Consecutive years individual has worked with current company \\
\hline Employer Size & Log of the number of employees in the firm in which the individual works \\
\hline Employer Age 0-2 & Dummy variable $=1$ if employer is between 0 and 2 years old \\
\hline Employer Age 3-6 & Dummy variable $=1$ if employer is between 3 and 6 years old \\
\hline Employer Age $>6$ & Dummy variable $=1$ if employer is $>6$ years old \\
\hline Hybrid Experience & $\begin{array}{l}\text { Dummy variable }=1 \text { if individual has at least } 1 \text { episode in self-employment in a secondary } \\
\text { labor status classification }\end{array}$ \\
\hline Swedish Citizen & If individual is a citizen of Sweden \\
\hline Partner & Dummy variable $=1$ if individual has a partner \\
\hline Partner Self-Employed & Dummy variable $=1$ if partner is self-employed \\
\hline Partner Income & Log of partner's total income \\
\hline Hybrid Self-Employment Income & Income or loss from self-employment activity (Kronor / 10000) \\
\hline Hybrid Intensity & Hybrid Self-Employment Income / Salary Income \\
\hline Hybrid Intensity 1 & Dummy variable $=1$ if: Hybrid Intensity $<-.05$ \\
\hline Hybrid Intensity 2 & Dummy variable $=1$ if: $-.05<=$ Hybrid Intensity $<0$ \\
\hline Hybrid Intensity 3 & Dummy variable $=1$ if: $0<=$ Hybrid Intensity $<.05$ \\
\hline Hybrid Intensity 4 & Dummy variable $=1$ if: $.05<=$ Hybrid Intensity $<.05$ \\
\hline Hybrid Intensity 5 & Dummy variable $=1$ if: $.20<=$ Hybrid Intensity \\
\hline
\end{tabular}




\section{HYBRID ENTREPRENEURSHIP}

\section{References}

Barley, S.R., G. Kunda. 2001. Bringing Work Back In. Organ. Sci.12 76-95.

Bates, T. 1990. Entrepreneur human capital and small business longevity. Rev.Econom.Statist.72 551-559.

Blanchflower, D. 2000. Self-employment in OECD countries.Labour Econ., 7 471-505.

Bruce, D., H.J. Schuetze. 2004. The labor market consequences of experience in selfemployment. Labour Econ., 11 575-598.

Burke, A.E., F.R. FitzRoy, M.A. Nolan. 2008. What makes a die-hard entrepreneur? Beyond the 'employee or entrepreneur' dichotomy. Small Bus. Econom.32 93-115.

Campbell,J.R., M. De Nardi 2007. A Conversation with 590 Nascent Entrepreneurs. Federal Reserve Bank of Chicago Working Paper No. 2007-20.

Caves, R.E. 1998. Industrial organization and new findings on the turnover and mobility of firms. J.Econom.Lit. 36 1947-1982.

Dixit, A., R. Rob. 1994. Switching costs and sectoral adjustments in general equilibrium with uninsured risk. J.Econom. Theory.62 48-69.

Elfenbein, D.W.., B.H. Hamilton, T.R. Zenger. 2008. The Entrepreneurial Spawning of Scientists and Engineers: Stars, Slugs, and the Small Firm Effect. Available at SSRN: http://ssrn.com/abstract=1098443

Evans, D.S., B. Jovanovic. 1989. An estimated model of entrepreneurial choice under liquidity constraints. J.Political Econom.97 808-827.

Evans, D.S., L.S. Leighton. 1989. Some empirical aspects of entrepreneurship. Amer. Econom. Rev. $79519-535$.

Gallagher, D.G. 2002. Contingent work contracts: Practice and theory. Cooper, C.L., Burke, R.J.,eds.The New World of Work: Challenges and Opportunities. Blackwell Publishers, Oxford, 115-36.

Gentry, W., G. Hubbard. 2000. Tax policy and entrepreneurial entry. Amer. Econom. Rev., 90 283-288.

Götzfried, A. 2004. European employment increasing in services and especially in knowledgeintensive services. Statistics in Focus: Science and Technology, 10. Eurostat, Catalogue number, KS-NS-04-010-EN-N.

Hamilton, B.H. 2000. Does entrepreneurship pay? An empirical analysis of the returns of selfemployment. J. Political Econom. 108 604-631. 


\section{HYBRID ENTREPRENEURSHIP}

Heckman, J.J., S. Navarro-Lozano. 2004. Using matching, instrumental variables, and control functions to estimate economic choice models. Rev. Econom. Statist. 86 30- 57.

Henrekson, M. 2005. Entrepreneurship: A weak link in the welfare state? Industrial and Corporate Change14 437-467.

Holmlund, B., D. Storrie. 2002. Temporary Work in Turbulent Times: The Swedish Experience. The Econom. J.112 245-269.

Hundley, G. 2001. Why and when are the self-employed more satisfied with their work? Industrial Relations.40 293-316.

Hyytinen, A., P. Rouvinen. 2008. The labour market consequences of self-employment spells: European evidence. Labour Econ. 15 246-271.

Hyytinen, A., P. Ilmakunnas. 2007. What distinguishes a serial entrepreneur? Industrial and Corporate Change16 793-821.

Jovanovic, B. 1982. Selection and the evolution of industry. Econometrica50 649-670.

Kalleberg, A.L. 2000. Nonstandard employment relations: Part-time, temporary and contract work. Annual Rev. Sociol. 26 341-365.

Kihlstrom, R.E., J.-J. Laffont 1979. A general equilibrium entrepreneurial theory of firm formation based on risk aversion. J. Political Econom.87 719-748.

Kimmel, J.,L.M.Powell. 1999. Moonlighting trends and related issues in Canada and the United States. Canadian Public Policy25 207-231.

Landier, A. (2005). Entrepreneurship and the Stigma of Failure. New York University, http://ssrn.com/abstract=850446.

Lucas, R. E., Jr. 1978. On the size distribution of business firms. Bell J. Econom. 92508-523.

Nanda, R., J. Sørensen. 2007. Peer effects and entrepreneurship. Stanford Business School Entrepreneurial Management Working Paper No. 08-051 SSRN.

O’Brien, J. P., Folta, T. B., Johnson, D. R. 2003. A real options perspective on enterpreneurial entry in the face of uncertainty. Managerial and Decision Econom.24 515-533.

Özcan, T. Reichstein 2009. Transition to Entrepreneurship from the Public Sector: Predispositional and Context Effects. Forthcoming. Management Sci.

Parker, S. C. 1996. A time series model of self-employment under uncertainty. Economica, 63 459-475.

---. 1997. The effects of risk on self-employment. Small Bus. Econom. 96 512-522.

---. 2005. The Economics of Entrepreneurship: What We Know and What We Don't. 


\section{HYBRID ENTREPRENEURSHIP}

Foundations and Trends in Entrepreneurship.1 1-54.

---. 2009. Why do small firms produce the entrepreneurs? Journal of Socio-Economics. In Press.

Petrova, K. 2005. Part-time entrepreneurship and wealth effects: New evidence from the Panel Study of Entrepreneurial Dynamics. Working Paper Boston College.

Renna 2006.Overtime and Moonlighting: A Cross-Country Analysis. J. Labor Research. 27 575591.

Reynolds, P. D., Carter, N. M., Gartner, W. B., Greene, P. G. 2004. The prevalence of nascent entrepreneurs in the United States: Evidence from the panel study of entrepreneurial dynamics. Small Bus.Econom.23 263-284.

Rotchford, N.L., K.H. Roberts. 1982. Part-time workers as missing persons in organizational research.Academy of Management Rev. 7 228-234.

Saxenian, A. 1985. The genesis of Silicon Valley. Hall, P., A. Markusen,eds. Silicon Landscapes. Allen \& Unwin, Boston, 20-34.

van der Sluis, J., C. M. Van Praag, W. Vijverberg. 2004.Education and Entrepreneurship in Industrialized Countries: A meta-analysis. Tinbergen Institute Discussion Paper.

Sørensen, J. 2007. Bureaucracy and entrepreneurship: Workplace effects on entrepreneurial entry. Adm. Sci. Quart.52 387-412.

Strohmeyer, R., V. Tonoyan. 2006. Working part- or full-time? The impact of welfare-state institutions on atypical work forms. Dowling, M., J. Schmude,eds. Empirical Entrepreneurship Research in Europe. Edward Elgar,Cheltenham.

Stuart, T. E., O. Sorenson. 2003. Liquidity events and the geographic distribution of entrepreneurial activity. Adm. Sci. Quart.48 175-201.

Taylor, M.P. 2001. Self-employment and windfall gains in Britain: Evidence from panel data. Economica68 539-565.

Tolbert, P.S. 1996. Occupations, organizations and boundaryless careers. M. Arthur, D. Rousseau, eds. Boundaryless Careers. NY: Oxford University Press, 91-107.

Van Maanen, J. 1975. Police socialization: A longitudinal examination of job attitudes in an urban police department Adm. Sci. Quart.20 207-228

Zucker, L.G., M.R. Darby. J. Armstrong. 1988. Geographically lovalized knowledge: Spillovers or markets? Econom. Inquiry.36 $65-86$ 
HYBRID ENTREPRENEURSHIP

Table 1 - Number and Percentage of Individuals in each Labor Classification per Year (1994-2001)

\begin{tabular}{|c|c|c|c|c|c|c|c|c|c|c|}
\hline & & 1994 & 1995 & 1996 & 1997 & 1998 & 1999 & 2000 & 2001 & Total \\
\hline \multirow{9}{*}{ 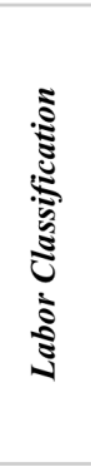 } & Wage Work & 44,613 & 42,985 & 41,275 & 39,904 & 38,605 & 37,537 & 36,587 & 35,757 & 317,263 \\
\hline & & 100 & 97.74 & 96.66 & 95.95 & 95.34 & 94.8 & 94.53 & 94.23 & 96.25 \\
\hline & & & & & & & & & & \\
\hline & Self-Employed & 0 & 311 & 599 & 914 & 1058 & 1191 & 1219 & 1225 & 6,517 \\
\hline & & 0 & 0.71 & 1.4 & 2.2 & 2.61 & 3.01 & 3.15 & 3.23 & 1.98 \\
\hline & Hybrid & 0 & 684 & 827 & 772 & 830 & 866 & 899 & 966 & 5844 \\
\hline & & 0 & 1.56 & 1.94 & 1.86 & 2.05 & 2.19 & 2.32 & 2.55 & $\begin{array}{r}5,044 \\
1.77\end{array}$ \\
\hline & Total & 44,613 & 43,980 & 42,701 & 41,590 & 40,493 & 39,594 & 38,705 & 37,948 & 329,624 \\
\hline & & 100.00 & 100.00 & 100.00 & 100.00 & 100.00 & 100.00 & 100.00 & 100.00 & 100.00 \\
\hline & & & & & & & & & & \\
\hline & & & & & & & & & & \\
\hline \multirow{12}{*}{ 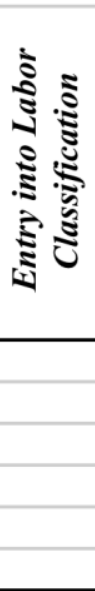 } & Self-Employed & & 311 & 362 & 443 & 350 & 341 & 284 & 236 & 2,327 \\
\hline & & & 31.26 & 42.09 & 53.18 & 44.19 & 45.71 & 42.39 & 36.20 & 41.94 \\
\hline & Hybrid & & 684 & 498 & 390 & 442 & 405 & 386 & 416 & 3,221 \\
\hline & & & 68.74 & 57.91 & 46.82 & 55.81 & 54.29 & 57.61 & 63.80 & 58.06 \\
\hline & & & & & & & & & & \\
\hline & Total & & 995 & 860 & 833 & 792 & 746 & 670 & 652 & 5,548 \\
\hline & & & 100.00 & 100.00 & 100.00 & 100.00 & 100.00 & 100.00 & 100.00 & 100.00 \\
\hline & & & & & & & & & & \\
\hline & \multirow{2}{*}{$\begin{array}{l}\text { Self-Employed Entry } \\
\text { preceded by Hybrid }\end{array}$} & & 0 & 90 & 94 & 61 & 72 & 52 & 37 & 406 \\
\hline & & & 0.00 & 33.09 & 26.93 & 21.11 & 26.77 & 22.41 & 18.59 & 21.13 \\
\hline & \multirow{2}{*}{$\begin{array}{l}\text { Self-Employed Entry not } \\
\text { preceded by Hybrid }\end{array}$} & & 311 & 272 & 349 & 289 & 269 & 232 & 199 & 1,921 \\
\hline & & & 100.00 & 66.91 & 73.07 & 78.89 & 73.23 & 77.59 & 81.41 & 78.87 \\
\hline
\end{tabular}




\section{HYBRID ENTREPRENEURSHIP}

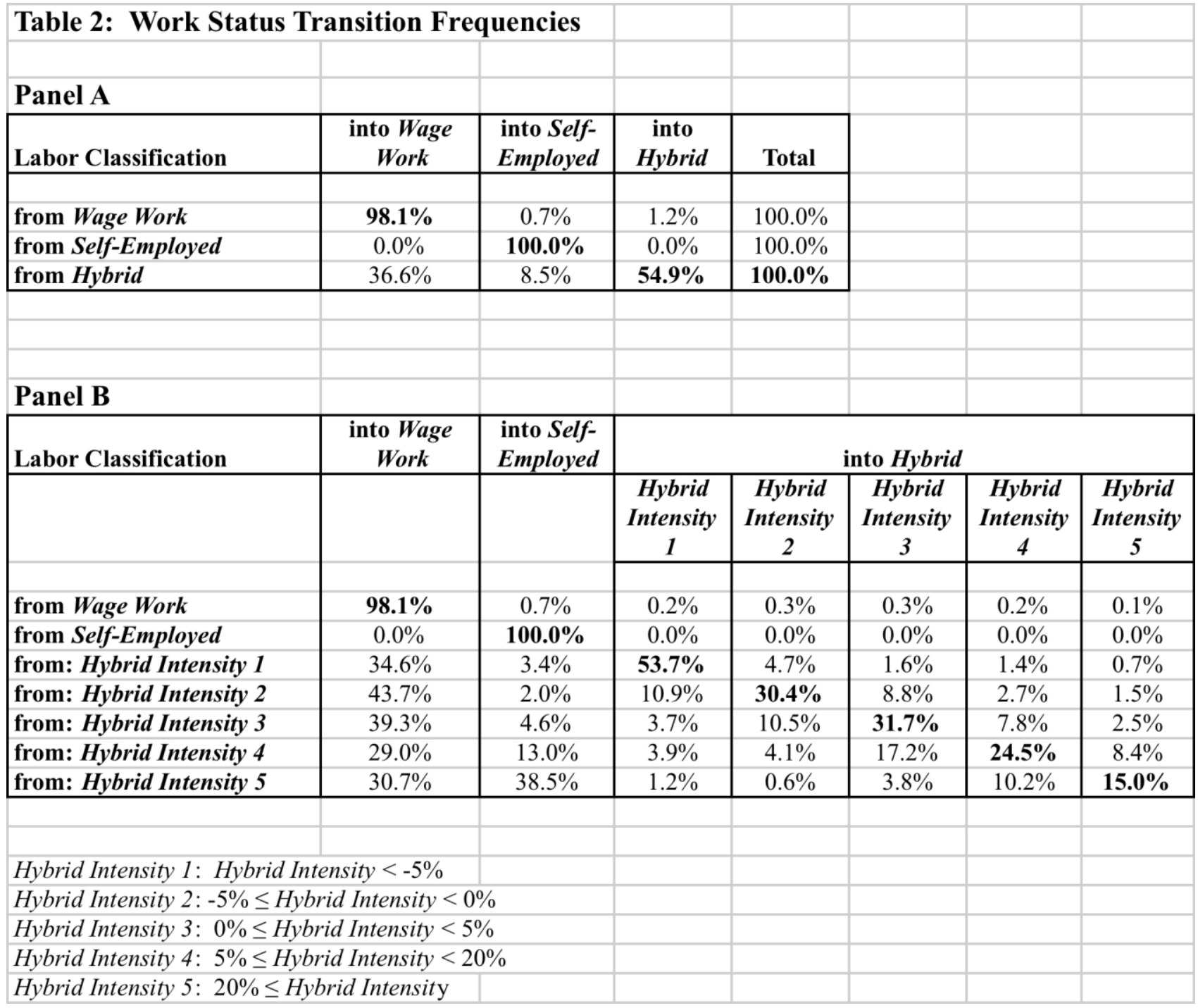


HYBRID ENTREPRENEURSHIP

Table 3: Means of Independent Variables by Type of Entry

\begin{tabular}{|c|c|c|c|c|c|}
\hline & No Entry & $\begin{array}{c}\text { Self- } \\
\text { Employed } \\
\text { Entry }\end{array}$ & $\begin{array}{c}\text { Self- } \\
\text { Employed } \\
\text { Entry Not } \\
\text { Preceded by } \\
\text { Hybrid }\end{array}$ & $\begin{array}{c}\text { Hybrid } \\
\text { Entry }\end{array}$ & $\begin{array}{c}\text { Difference } \\
\text { between } \\
\text { (3) \& (4) }\end{array}$ \\
\hline Variables & (1) & (2) & (3) & (4) & (5) \\
\hline Salary Income (before log) & $284,694.6$ & $223,820.3$ & $233,383.6$ & $276,394.9$ & $* * *$ \\
\hline 1st Quintile & 0.184 & 0.419 & 0.386 & 0.190 & $* * *$ \\
\hline 2nd Quintile & 0.204 & 0.134 & 0.129 & 0.175 & $* * *$ \\
\hline 3rd Quintile & 0.204 & 0.137 & 0.144 & 0.186 & $* * *$ \\
\hline 4th Quintile & 0.204 & 0.141 & 0.151 & 0.216 & $* * *$ \\
\hline 5th Quintile & 0.204 & 0.170 & 0.191 & 0.233 & $* * *$ \\
\hline Negative Change in Salary Income & 1.126 & 0.596 & 0.143 & 0.051 & $* * *$ \\
\hline Non-Salary Income & 13.350 & 95.944 & 133.954 & -57.484 & $*$ \\
\hline Negative Change in Non-Salary Income & -0.111 & -1.200 & 0.272 & 0.269 & \\
\hline Household Wealth & 0.715 & 0.794 & 0.813 & 0.687 & \\
\hline Household Wealth Dummy & 0.050 & 0.055 & 0.057 & 0.048 & \\
\hline Married & 0.483 & 0.501 & 0.501 & 0.530 & * \\
\hline Number of Children & 0.914 & 1.000 & 0.991 & 1.049 & \\
\hline Education Percentile & 0.499 & 0.501 & 0.501 & 0.555 & $* * *$ \\
\hline Total Number of Jobs & 3.618 & 4.073 & 4.125 & 3.876 & $* * *$ \\
\hline Time Unemployed & 0.540 & 1.152 & 1.214 & 0.623 & $* * *$ \\
\hline Age $25-30$ & 0.114 & 0.090 & 0.096 & 0.113 & \\
\hline Age $30-35$ & 0.248 & 0.260 & 0.263 & 0.243 & \\
\hline Age $40-45$ & 0.163 & 0.168 & 0.170 & 0.176 & \\
\hline Age $45-50$ & 0.146 & 0.163 & 0.161 & 0.151 & \\
\hline Age $>50$ & 0.124 & 0.109 & 0.102 & 0.094 & \\
\hline Self-Employment Experience & 0.022 & 0.101 & 0.100 & 0.060 & $* * *$ \\
\hline Target Industry Experience & 0.721 & 0.403 & 0.438 & 0.103 & $* * *$ \\
\hline Parental Self-Employment Experience & 0.033 & 0.092 & 0.093 & 0.092 & \\
\hline Industry Tenure & 1.418 & 1.095 & 1.067 & 1.277 & $* * *$ \\
\hline Employer Tenure & 3.153 & 2.632 & 2.449 & 2.443 & \\
\hline Employer Size & 6.534 & 4.195 & 3.933 & 6.042 & $* * *$ \\
\hline Employer Age 0-2 & 0.179 & 0.247 & 0.267 & 0.207 & $* * *$ \\
\hline Employer Age 3-6 & 0.136 & 0.085 & 0.083 & 0.068 & $*$ \\
\hline Employer Age $>6$ & 0.685 & 0.668 & 0.650 & 0.725 & $* * *$ \\
\hline Hybrid Experience & 0.069 & 0.378 & 0.438 & 0.103 & $* * *$ \\
\hline Swedish Citizen & 0.903 & 0.919 & 0.924 & 0.917 & \\
\hline Partner & 0.608 & 0.612 & 0.615 & 0.647 & $*$ \\
\hline Partner Self-Employed & 0.009 & 0.025 & 0.021 & 0.024 & \\
\hline Partner Income (before log) & $86,486.8$ & $84,445.8$ & $84,239.2$ & $88,300.8$ & \\
\hline Observations & 317,263 & 2,327 & 1,921 & 3,221 & \\
\hline
\end{tabular}

$* \mathrm{p}<0.05, * * \mathrm{p}<0.01,{ }^{* * *} \mathrm{p}<.001$ 
HYBRID ENTREPRENEURSHIP

Table 4: Change in Income After Hybrid Entry (SEK)

\begin{tabular}{|c|c|c|c|c|c|c|c|c|}
\hline & $\begin{array}{l}\text { Mean Salary } \\
\text { Income year } \\
\text { before entry }\end{array}$ & $\begin{array}{c}\text { Mean Salary } \\
\text { Income year } \\
\text { of entry }\end{array}$ & $\begin{array}{l}\text { Mean Self- } \\
\text { Employment } \\
\text { Income year } \\
\text { of entry }\end{array}$ & $\begin{array}{c}\text { Mean total } \\
\text { income } \\
\text { year of } \\
\text { entry }\end{array}$ & $\begin{array}{c}\text { Difference } \\
\text { in mean } \\
\text { Salary } \\
\text { Income } \\
(2-1)\end{array}$ & $\begin{array}{c}\% \\
\text { difference } \\
\text { in mean } \\
\text { Salary } \\
\text { Income } \\
(5 / 1)^{*}\end{array}$ & $\begin{array}{c}\text { Standard } \\
\text { deviation } \\
\text { Self- } \\
\text { Employment } \\
\text { Income year } \\
\text { of entry } \\
\end{array}$ & $\begin{array}{c}\# \text { of } \\
\text { Hybrids }\end{array}$ \\
\hline & 1 & 2 & 3 & 4 & 5 & 6 & 7 & 8 \\
\hline All Hybrids & $265,543.6$ & $278,805.0$ & 922.0 & $279,727.0$ & $13,261.4$ & $5.0 \%$ & $78,991.0$ & 3221 \\
\hline 1st centile of Salary Income in 1994 & $191,819.6$ & $185,068.6$ & 100.7 & $185,169.3$ & $-6,751.0$ & $-3.5 \%$ & $35,221.0$ & 611 \\
\hline 2nd centile of Salary Income in 1994 & $203,771.9$ & $209,224.5$ & $-8,052.4$ & $201,172.1$ & $5,452.6$ & $2.7 \%$ & $79,970.8$ & 626 \\
\hline 3rd centile of Salary Income in 1994 & $216,786.1$ & $224,971.3$ & -909.5 & $224,061.8$ & $8,185.2$ & $3.8 \%$ & $49,330.7$ & 568 \\
\hline 4th centile of Salary Income in 1994 & $272,663.5$ & $288,060.2$ & -321.5 & $287,738.7$ & $15,396.7$ & $5.6 \%$ & $49,762.6$ & 675 \\
\hline 5th centile of Salary Income in 1994 & $409,406.9$ & $447,712.7$ & $11,717.5$ & $459,430.2$ & $38,305.8$ & $9.4 \%$ & $128,129.4$ & 741 \\
\hline
\end{tabular}

Centiles are at $0-20,20-40,40-60,60-80, \& 80-100$ percentiles repectively.

* Inflation rates in Sweden were below 3\% during the risk period 
Table 5: Multinomial Logit (No Entry, Self-Employed Entry, \& Hybrid Entry)

Column (1) compares Self-Employment Entry versus the alternative of No Entry. Self-Employment entry is defined as not being preceded by Hybrid status, as reported in column (3) of Table 6. Column (2) compares Hybrid Entry versus the alternative of No Entry. Hybrid entry as moving directly from wage work into hybrid status, as reported in column (4) of Table 6. Column (3) reports significant differences between Self-Employment Entry and Hybrid Entry. Columns (4-6) report marginal effects at the the mean of each variable, which is the percentage change in the entry choice with a 1 unit change in the independent variable.

\begin{tabular}{|c|c|c|c|c|c|c|c|c|c|c|c|c|c|}
\hline \multirow{3}{*}{ Variables } & \multicolumn{7}{|c|}{ Coefficients and Standard Errors } & \multicolumn{6}{|c|}{$\begin{array}{l}\text { Marginal Effects at Mean of Each Variable } \\
\text { (Percent change in Entry choice with a } 1 \text { unit } \\
\text { change in independent variable) }\end{array}$} \\
\hline & \multirow{2}{*}{\multicolumn{3}{|c|}{$\begin{array}{l}\text { Self-Employed Entry } \\
\text { Preferred to No Entry } \\
1\end{array}$}} & \multirow{2}{*}{\multicolumn{3}{|c|}{$\begin{array}{c}\text { Hybrid Entry } \\
\text { Preferred to No } \\
\text { Entry } \\
2 \\
\end{array}$}} & \multirow{3}{*}{$\begin{array}{c}\text { Difference } \\
\text { in (2) vs (3) } \\
3 \\
\end{array}$} & \multirow{2}{*}{\multicolumn{2}{|c|}{$\begin{array}{c}\text { No Entry } \\
4\end{array}$}} & \multirow{2}{*}{\multicolumn{2}{|c|}{$\begin{array}{c}\begin{array}{c}\text { Self } \\
\text { Employed } \\
\text { Entry }\end{array} \\
5\end{array}$}} & \multirow{2}{*}{\multicolumn{2}{|c|}{$\begin{array}{c}\text { Hybrid Entry } \\
6\end{array}$}} \\
\hline & & & & & & & & & & & & & \\
\hline Salary Income & 0.270 & **** & $(0.02)$ & 0.259 & *** & $(0.03)$ & & -0.257 & *** & 0.063 & *** & 0.194 & *** \\
\hline Negative Change in Salary Income & 2.953 & *** & $(0.17)$ & 0.713 & *** & $(0.18)$ & $* * *$ & -1.220 & *** & 0.691 & $* * *$ & 0.529 & $* * *$ \\
\hline Non-Salary Income $(100,000)$ & -0.062 & & $(0.42)$ & -1.120 & & $(1.68)$ & & 0.854 & & -0.013 & & -0.841 & \\
\hline Negative Change in Non-Salary Income & 0.071 & * & $(0.03)$ & 0.061 & * & $(0.02)$ & & $-0.062=$ & $* * *$ & 0.017 & * & 0.045 & * \\
\hline Household Wealth & -0.272 & & $(0.16)$ & -0.270 & & $(0.15)$ & & 0.265 & * & -0.063 & & -0.202 & \\
\hline Household Wealth Dummy & 3.890 & & (2.24) & 3.721 & & (2.15) & & -25.517 & & 6.857 & & 18.660 & \\
\hline Married & 0.099 & & $(0.08)$ & 0.089 & & $(0.06)$ & & -0.090 & & 0.023 & & 0.067 & \\
\hline Number of Children & 0.065 & * & $(0.03)$ & 0.058 & * & $(0.02)$ & & -0.058 & ** & 0.015 & * & 0.043 & * \\
\hline Education Percentile & 0.001 & & $(0.09)$ & 0.285 & $* * *$ & $(0.08)$ & * & -0.213 & $* * *$ & 0.000 & & 0.214 & $* * *$ \\
\hline Total Number of Jobs & 0.134 & *** & $(0.02)$ & 0.055 & $* *$ & $(0.02)$ & $* *$ & -0.072 & $* * *$ & 0.031 & *** & $0.041=$ & $* *$ \\
\hline Time Unemployed & 0.058 & $* * *$ & $(0.02)$ & -0.043 & ** & $(0.01)$ & $* * *$ & 0.019 & & 0.014 & $* * *$ & -0.033 & ** \\
\hline Age $25-30^{\mathrm{a}}$ & -0.373 & $* * *$ & $(0.10)$ & -0.131 & & $(0.08)$ & & 0.170 & ** & -0.076 & $* * *$ & -0.093 & \\
\hline Age $30-35^{\mathrm{a}}$ & -0.066 & & $(0.07)$ & -0.091 & & $(0.06)$ & & 0.082 & & -0.015 & & -0.067 & \\
\hline Age $40-45^{\mathrm{a}}$ & -0.027 & & $(0.08)$ & -0.065 & & $(0.06)$ & & 0.053 & & -0.006 & & -0.047 & \\
\hline Age $45-50^{\mathrm{a}}$ & 0.087 & & $(0.08)$ & -0.048 & & $(0.07)$ & & 0.015 & & 0.021 & & -0.036 & \\
\hline Age $>50^{\mathrm{a}}$ & 0.061 & & $(0.10)$ & -0.050 & & $(0.08)$ & & 0.022 & & 0.015 & & -0.037 & \\
\hline Self-Employment Experience & -0.140 & & $(0.12)$ & -0.582 & $* * *$ & $(0.10)$ & ** & 0.368 & $* * *$ & -0.030 & & -0.338 & $* * *$ \\
\hline Parental Self-Employment Experience & 0.718 & *** & $(0.09)$ & 0.917 & *** & $(0.07)$ & & -1.307 & $* * *$ & 0.234 & *** & 1.072 & $* * *$ \\
\hline Industry Tenure & -0.317 & *** & $(0.03)$ & -0.077 & ** & $(0.02)$ & *** & 0.131 & *** & -0.074 & *** & -0.057 & ** \\
\hline Employer Tenure & -0.172 & ** & $(0.06)$ & -0.498 & *** & $(0.04)$ & $* * *$ & 0.412 & *** & -0.039 & ** & -0.373 & $* * *$ \\
\hline Employer Tenure - squared & 0.024 & *** & $(0.01)$ & 0.047 & $* * *$ & $(0.00)$ & $* *$ & -0.041 & $* * *$ & 0.005 & *** & 0.035 & $* * *$ \\
\hline Employer Size & -0.229 & *** & $(0.01)$ & -0.018 & & $(0.01)$ & *** & 0.067 & *** & -0.054 & **** & -0.013 & *** \\
\hline Employer Age 0-2 Years ${ }^{\mathrm{b}}$ & 0.066 & * & $(0.07)$ & -0.004 & & $(0.05)$ & & -0.012 & & 0.016 & & -0.003 & \\
\hline Employer Age 3-6 Years ${ }^{\text {b }}$ & -0.039 & & $(0.10)$ & -0.215 & ** & $(0.08)$ & & 0.158 & $* * *$ & -0.009 & & -0.150 & $* *$ \\
\hline Hybrid Experience & 0.842 & $* * *$ & $(0.08)$ & 1.501 & $* * *$ & $(0.05)$ & $* * *$ & -2.514 & $* * *$ & 0.276 & *** & 2.238 & $* * *$ \\
\hline Swedish Citizen & -0.057 & & $(0.10)$ & 0.014 & & $(0.07)$ & & 0.003 & & -0.014 & & 0.010 & \\
\hline Partner & -0.111 & & $(0.13)$ & 0.105 & & $(0.09)$ & & -0.051 & & -0.027 & & 0.078 & \\
\hline Partner Self-Employed & 0.549 & ** & $(0.17)$ & 0.623 & *** & $(0.13)$ & & -0.805 & *** & 0.168 & * & 0.637 & *** \\
\hline Partner Income & -0.003 & & $(0.01)$ & -0.016 & ** & $(0.01)$ & & 0.013 & ** & -0.001 & & -0.012 & $* *$ \\
\hline Industry Dummies (55) & & & & Yes & & & & Yes & & Yes & & Yes & \\
\hline Region Dummies (21) & & & & Yes & & & & Yes & & Yes & & Yes & \\
\hline Year Dummies (7) & & & & Yes & & & & Yes & & Yes & & Yes & \\
\hline Log Likelihood & & & & -23389.44 & & & & & & & & & \\
\hline Psuedo R-squared & & & & 0.097 & & & & & & & & & \\
\hline \# of Observations & & & & 259,856 & & & & & & & & & \\
\hline Probability of Choice & & & & & & & & $99.01 \%$ & & $0.24^{\circ}$ & & $0.75 \%$ & \\
\hline Compared against omitted category $\mathrm{A}$ & $35-40$ & & & & & & & & & & & & \\
\hline${ }^{\mathrm{b}}$ Compared against omitted category Er & ployer Ag & ge $>6$ & ears & & & & & & & & & & \\
\hline$* * * \mathrm{p}<0.001, * * \mathrm{p}<0.01, * \mathrm{p}<.05 ;$ rol & Just santac & & & & & & & & & & & & \\
\hline
\end{tabular}


Table 6: Conditional Fixed Effects Logistic Regression (Self-Employed Entry (1) \& No Entry (0))

Columns 1-5 consider all 2327 men entering Self-Employed, enabling us to examine the consequences of Hybrid activity on Self-Employed entry. Column 6 combines Hybrid entries with the 1921 Self-Employed entries directly from wage work, like most studies examining entry into selfemployment. A comparison of the coefficients across the two different ways to identify self-employment entry highlights the consequences of representing Hybrid entries as self-employment entries.

\begin{tabular}{|c|c|c|c|c|c|c|}
\hline \multirow[t]{2}{*}{ Variables } & \multicolumn{5}{|c|}{ Self-Employed entry preferred to no entry } & \multirow[t]{2}{*}{$\begin{array}{c}\text { Self-Employed } \\
\text { entry \& Hybrid } \\
\text { entry preferred } \\
\text { to no entry } \\
(6)\end{array}$} \\
\hline & $(1)$ & (2) & $(3)$ & 4.000 & 5.000 & \\
\hline \multirow[t]{2}{*}{ Hybrid } & & $3.644 * * *$ & $3.214 * * *$ & $2.845 * * *$ & & \\
\hline & & $(0.238)$ & $(0.248)$ & $(0.270)$ & & \\
\hline \multirow[t]{2}{*}{ Hybrid SE Income (10000) } & & & $0.165 * * *$ & & & \\
\hline & & & $(0.035)$ & & & \\
\hline \multirow[t]{2}{*}{ Hybrid Intensity } & & & & $1.735 * * *$ & & \\
\hline & & & & $(0.400)$ & & \\
\hline \multirow[t]{2}{*}{ Hybrid Intensity 1} & & & & & $1.294 * *$ & \\
\hline & & & & & $(0.398)$ & \\
\hline \multirow[t]{2}{*}{ Hybrid Intensity 2} & & & & & 0.708 & \\
\hline & & & & & $(0.459)$ & \\
\hline \multirow[t]{2}{*}{ Hybrid Intensity 4} & & & & & $3.336 * * *$ & \\
\hline & & & & & $(0.366)$ & \\
\hline \multirow[t]{2}{*}{ Hybrid Intensity 5} & & & & & $4.968 * * *$ & \\
\hline & & & & & $(0.379)$ & \\
\hline \multirow[t]{2}{*}{ Salary Income } & $1.203 * * *$ & $1.275^{* * *}$ 氺 & $1.181 * * *$ & $1.203 * * *$ & $1.322 * * *$ & $0.416^{* * *}$ \\
\hline & $(0.060)$ & $(0.070)$ & $(0.071)$ & $(0.072)$ & $(0.073)$ & $(0.021)$ \\
\hline \multirow[t]{2}{*}{ Non-Salary Income } & 0.000 & 0.000 & 0.000 & 0.000 & 0.000 & 0.000 \\
\hline & $(0.000)$ & $(0.000)$ & $(0.000)$ & $(0.000)$ & $(0.000)$ & $(0.000)$ \\
\hline \multirow[t]{2}{*}{ Household Wealth } & -0.335 & 0.108 & -0.059 & -0.084 & 0.102 & -0.264 \\
\hline & $(0.529)$ & $(0.620)$ & $(1.032)$ & $(0.996)$ & $(0.642)$ & $(0.225)$ \\
\hline \multirow[t]{2}{*}{ Household Wealth Dummy } & 4.809 & -1.420 & 1.827 & 2.117 & -1.433 & 3.763 \\
\hline & $(7.472)$ & $(8.740)$ & $(14.569)$ & $(14.092)$ & $(9.056)$ & $(3.174)$ \\
\hline Married & 0.437 & 0.586 & $1.488^{*}$ & $1.455^{*}$ & 0.405 & 0.062 \\
\hline & $(0.368)$ & $(0.410)$ & $(0.731)$ & $(0.740)$ & $(0.414)$ & $(0.120)$ \\
\hline \# Children & $0.451^{* *}$ & $0.446 * *$ & 0.335 & 0.319 & $0.479 * *$ & 0.018 \\
\hline & $(0.146)$ & $(0.161)$ & $(0.275)$ & $(0.274)$ & $(0.162)$ & $(0.044)$ \\
\hline Education Percentile & 0.217 & 0.167 & -6.108 & -6.409 & 0.940 & 0.123 \\
\hline & $(1.983)$ & $(2.088)$ & $(3.421)$ & $(3.445)$ & $(2.241)$ & $(0.368)$ \\
\hline Total \# of Jobs & 27.963 & 28.414 & 34.393 & 32.725 & 29.610 & $0.902^{* * *}$ \\
\hline & $(653.572)$ & $(402.314$ & $(1,758.99$ & $(682.064)$ & $(733.782)$ & $(0.037)$ \\
\hline Time Unemployed & $0.301 * * *$ & $0.286 * * *$ & $0.263 * * *$ & $0.255 * * *$ & $0.291 * * *$ & $0.056^{* * *}$ \\
\hline & $(0.035)$ & $(0.039)$ & $(0.065)$ & $(0.065)$ & $(0.039)$ & $(0.013)$ \\
\hline Age $25-30$ & 0.514 & 0.405 & $-4.566 * *$ & $-4.515 * *$ & 0.350 & -0.101 \\
\hline & $(0.373)$ & $(0.424)$ & $(1.408)$ & $(1.392)$ & $(0.426)$ & $(0.127)$ \\
\hline Age $30-35$ & 0.458 & 0.462 & -0.638 & -0.527 & 0.409 & -0.056 \\
\hline & $(0.236)$ & $(0.268)$ & $(0.587)$ & $(0.559)$ & $(0.270)$ & $(0.080)$ \\
\hline Age $40-45$ & -0.348 & -0.166 & -0.087 & -0.362 & -0.088 & -0.108 \\
\hline & $(0.282)$ & $(0.349)$ & $(0.579)$ & $(0.549)$ & $(0.345)$ & $(0.089)$ \\
\hline Age $45-50$ & -0.103 & -0.005 & -0.037 & -0.249 & 0.077 & -0.142 \\
\hline & $(0.423)$ & $(0.491)$ & $(0.794)$ & $(0.773)$ & $(0.493)$ & $(0.139)$ \\
\hline Age $>50$ & -0.537 & -0.497 & -0.679 & -0.921 & -0.316 & -0.079 \\
\hline & $(0.529)$ & $(0.612)$ & $(0.980)$ & $(0.960)$ & $(0.613)$ & $(0.185)$ \\
\hline Industry Tenure & $-2.421 * *$ & $-3.416 * *$ & $-1.774 * *:$ & $-1.556^{* *}$ & $-3.419 * * *$ & $-0.594 * * *$ \\
\hline & $(0.234)$ & $(0.288)$ & $(0.522)$ & $(0.514)$ & $(0.286)$ & $(0.073)$ \\
\hline Employer Tenure & $2.228 * * *$ & $2.023 * * *$ & $3.722 * * *$ & $3.762 * * *$ & $2.115^{* * * *}$ & $-0.264 * * *$ \\
\hline & $(0.130)$ & $(0.149)$ & $(0.275)$ & $(0.277)$ & $(0.146)$ & $(0.035)$ \\
\hline Employer Tenure squared & $-0.065 * *$ & -0.006 & $-0.117 * * *$ & $-0.123 * * *$ & -0.020 & $0.036^{* * * *}$ \\
\hline & $(0.014)$ & $(0.017)$ & $(0.028)$ & $(0.028)$ & $(0.016)$ & $(0.005)$ \\
\hline Employer Age 0-2 Years & $-1.970 * *=$ & $-1.900 * *$ & 1.263 & 1.390 & $-1.985 * * *$ & $-0.147^{*}$ \\
\hline & $(0.217)$ & $(0.251)$ & $(0.842)$ & $(0.815)$ & $(0.256)$ & $(0.059)$ \\
\hline Employer Age 3-6 Years & $-2.440 * *$ & $-2.568 * *$ & 1.206 & 1.405 & $-2.621 * * *$ & -0.040 \\
\hline & $(0.288)$ & $(0.312)$ & $(0.956)$ & $(0.933)$ & $(0.321)$ & $(0.087)$ \\
\hline Partner Dummy & $-1.208 * *$ & $-1.193^{*}$ & -0.425 & -0.491 & $-1.027^{*}$ & -0.138 \\
\hline & $(0.428)$ & $(0.481)$ & $(0.838)$ & $(0.844)$ & $(0.480)$ & $(0.143)$ \\
\hline Partner in Self-Employment & -0.231 & -0.501 & $-1.372 *$ & -1.209 & -0.279 & 0.012 \\
\hline & $(0.347)$ & $(0.393)$ & $(0.650)$ & $(0.639)$ & $(0.415)$ & $(0.152)$ \\
\hline Patner Income & 0.013 & 0.009 & -0.051 & -0.044 & 0.002 & 0.001 \\
\hline & $(0.025)$ & $(0.028)$ & $(0.048)$ & $(0.047)$ & $(0.028)$ & $(0.008)$ \\
\hline Log Likelihood & -1011.88 & -800.732 & -785.205 & -529.170 & -798.091 & -7270.338 \\
\hline Observations & & & 12941 & & & 27782 \\
\hline Number of lind & & & 2253 & & & 4437 \\
\hline$* * * \mathrm{p}<0.001, * * \mathrm{p}$ & ; sta & & 1eses & & & \\
\hline
\end{tabular}

